Izabela SAMSON-BRĘK

Krzysztof BIERNAT

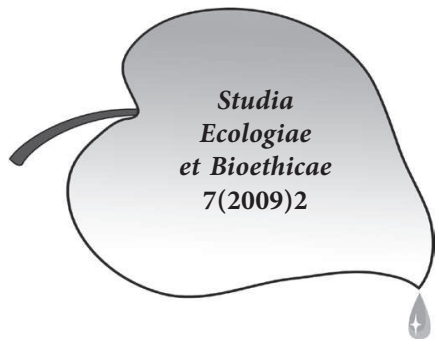

IEiB WFCh UKSW Warszawa

\title{
Możliwości wykorzystania biogazu rolniczego do produkcji paliwa silnikowego
}

\section{Wprowadzenie}

Biogaz jest gazem wytwarzanym przez mikroorganizmy w warunkach beztlenowych na drodze fermentacji metanowej materii organicznej. Dyrektywa 2003/30/UE definiowała biogaz jako paliwo gazowe produkowane $z$ biomasy i/lub ulegającej biodegradacji części odpadów, które może być oczyszczone do jakości gazu naturalnego, do użycia jako biopaliwo lub gaz drzewny.

Dyrektywa 2009/28/UE, uchylając dyrektywę 2003/30/UE, wprowadza kompleksową definicję „energii z źródeł odnawialnych”, gdzie „energia ze źródeł odnawialnych" oznacza energię $z$ odnawialnych źródeł niekopalnych, a mianowicie energię wiatru, energie promieniowania słonecznego, energię aerotermalną, geotermalna, hydrotermalna i energię oceanów, hydroenergię, energię pochodzaca z biomasy, gazu pochodzącego z wysypisk odpadów, oczyszczalni ścieków i ze źródet biologicznych (biogaz).

Produkcja biogazu rolniczego oraz jego energetyczne wykorzystanie jest obecnie jedną z korzystnych metod pozyskiwania energii. Mimo to technologia ta nie jest jeszcze rozpowszechniona w Polsce, natomiast znalazła już powszechne zastosowanie w krajach takich, jak Niemcy, Austria czy Szwecja. W Polsce, korzystając z doświadczeń tych państw, do roku 2030 ma powstać 2500 biogazowni rolniczych. Idea tworzenia biogazowni w każdej gminie potwierdzona jest przez Politykę Energetyczną Polski (PEP) do 2030.

$\mathrm{Z}$ uwagi na wysoki potencjał pozyskiwania surowca do produkcji biogazu w Polsce, jego energetyczne wykorzystanie może okazać się szansą na osiągnięcie 7,5\% udziału energii elektrycznej wytwarzanej z odnawialnych źródeł energii do 2010 roku oraz 5,75\% udziału biopaliw w strukturze paliw transportowych.

Argumentem przemawiającym na korzyść nośnika energii, jakim jest biogaz, są również substraty służące do jego wytwarzania, które nie konkurują z produkcją żywności. Głównymi źródłami biogazu rolniczego są płynne lub sta- 
łe odchody zwierzęce, pozostałości z rolnictwa oraz pozostałości z przemysłu rolno-spożywczego. Możliwości ponownego wykorzystania produktów, które do tej pory uważane były za zbędne oraz nie posiadały cech towaru mogą korzystnie wpływać na wzrost konkurencyjności przetwórstwa rolno-spożywczego na wsi oraz spowodować wzrost przychodów rolniczych, jak to przedstawiono na rys. 1.

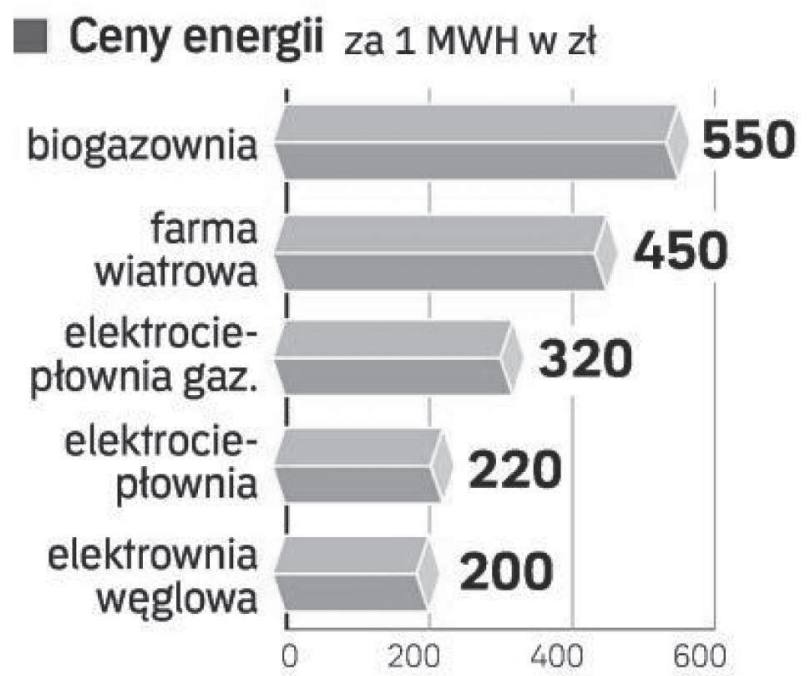

Rys. 1. Porównanie cen energii z biogazu z cenami innych nośników energii

Źródło: Kozmana M., „Biogaz - polska żyła złota?”, Rzeczpospolita.

\section{Surowce do produkcji biogazu}

Biogaz może być wytwarzany z różnorodnych substratów. Ze względu na pochodzenie substraty dzielą się na rolnicze, miejskie oraz z przemysłu rolnospożywczego. Rodzaj substratu jest również czynnikiem decydującym o podziale biogazowni na rolnicze oraz przemysłowe.

Jednym z głównych substratów wykorzystywanych do produkcji biogazu rolniczego są odpady z produkcji rolniczej. Odpady te, których podstawowe rodzaje przedstawiono na rys. 2, to kluczowy dla biogazowni rolniczej rodzaj podłoży. Powstają one podczas produkcji zwierząt i zalicza się do nich gnojówkę, gnojowicę, obornik, uprawy energetyczne oraz odpady z produkcji roślin. 


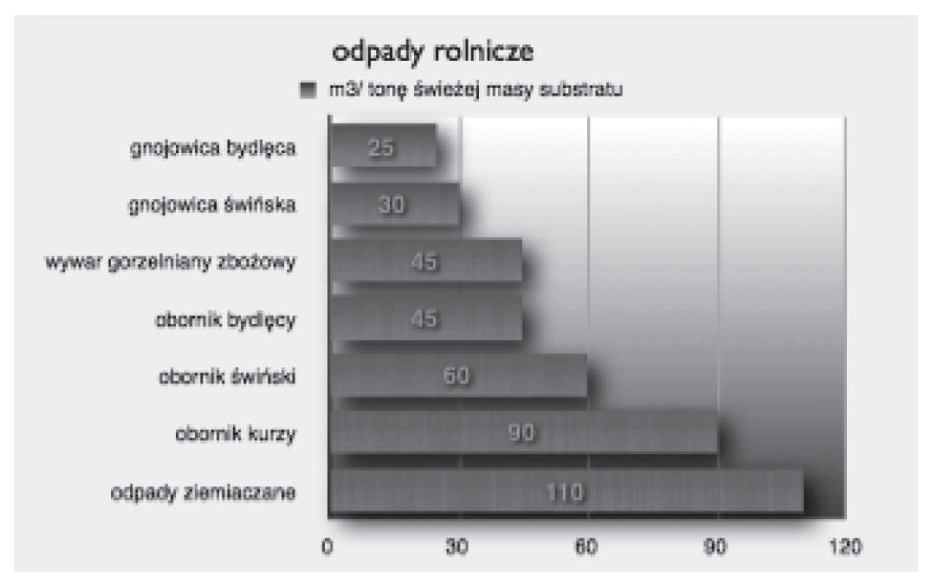

Rys. 2. Wydajność odpadów rolniczych w procesie produkcji biogazu Źródło: http://www.biogaz.com.pl/index.php/home/66-substraty.

Istotną rolę w procesie produkcji biogazu odgrywa gnojówka oraz gnojowica. Ze statystyk płynących z gospodarstw niemieckich wynika, że tylko chów krów oraz świń niesie za sobą olbrzymi potencjał podłoży, które nadają się do użycia $\mathrm{w}$ instalacjach biogazowych. W związku z ciągle rosnącymi potrzebami żywnościowymi, a co za tym idzie intensyfikacją produkcji rolnej, dostępność surowca w postaci gnojówki i gnojowicy ciągle wzrasta. Wykorzystanie odchodów zwierzęcych do produkcji energii jest korzystne nie tylko z energetycznego punktu widzenia, ale również pozwala na spełnienie wymogów dotyczących ochrony środowiska.

Uzysk biogazu z gnojowicy bydła jest jednak niższy niż w przypadku uzysku z gnojowicy świń. Spowodowane jest to tym, że niestrawione resztki pokarmu ulegają wstępnej fermentacji już w żołądku bydła, przez co gnojowica bydlęca jest uboższa w metan. W tabeli 1 przedstawiono uzysk biogazu oraz zawartość metanu w zależności od rodzaju podłoża naturalnego.

Tabela 1. Zawartość metanu oraz uzysk biogazu w nawozach naturalnych

\begin{tabular}{|c|c|c|c|}
\hline \multirow{2}{*}{ Rodzaj podłoża } & \multicolumn{2}{|c|}{ Uzysk biogazu } & \multirow{2}{*}{$\begin{array}{c}\text { Zawartość metanu } \\
{[\% \text { obj. }]}\end{array}$} \\
\hline & [m³/t podłoża] & {$\left[\mathrm{m}^{3} / \mathrm{t} \mathrm{smo}\right]$} & \\
\hline Gnojowica bydła & $20-30$ & $200-500$ & 60 \\
\hline Gnojowica świń & $20-35$ & $300-700$ & $60-70$ \\
\hline Obornik bydła & $40-50$ & $210-300$ & 60 \\
\hline Obornik świń & $55-65$ & $270-450$ & 60 \\
\hline
\end{tabular}

Źródło: Institut für Energetik und Umwelt gGmbH, „Biogaz - produkcja, wykorzystanie“ 
Odpady z przemystu rolno-spożywczego również są cennym surowcem wykorzystywanym do produkcji biogazu. Mogą stanowić podłoża samodzielne lub też być dodawane do gnojowicy bydła i świń jako współsubstraty, w celu ich zagęszczenia.

Jednym z przykładów wykorzystania odpadów z przemysłu rolno-spożywczego jest tzw. „wycierka ziemniaczana” będąca produktem ubocznym powstającym przy produkcji skrobi. Składa się ona głównie z łupin, błon komórkowych oraz komórek skrobi pozostałych po jej odzyskaniu. Szacuje się, że na jedną tonę przetworzonych ziemniaków przypada ok. $240 \mathrm{~kg}$ wycierki.

Obecnie wycierka ziemniaczana przekazywana jest gospodarstwom rolnym z przeznaczeniem na paszę, zaś pozostałe odpady w postaci ścieków organicznych rozlewane są na polach jako nawóz. Jednak wykorzystanie wycierki przez rolników jest niewielkie, zaś zbyt częste nawożenie gleby powoduje jej przenawożenie oraz zasolenie wód gruntowych.

Alternatywą w sposobie gospodarowania wyżej wymienionymi odpadami jest ich wykorzystanie na potrzeby biogazowni, gdyż stanowią one dobrze fermentujące podłoże. W tabeli 2 przedstawiono uzysk biogazu oraz zawartość metanu w substancjach odpadowych powstających podczas produkcji skrobi.

Tabela 2. Uzysk biogazu oraz zawartość metanu w produktach ubocznych przy pozyskiwaniu skrobi

\begin{tabular}{|c|c|c|c|}
\hline \multirow{2}{*}{ Rodzaj podłoża } & \multicolumn{2}{|c|}{ Uzysk biogazu } & \multirow{2}{*}{$\begin{array}{c}\text { Zawartość metanu } \\
{[\% \text { obj. }]}\end{array}$} \\
\hline & {$\left[\mathrm{m}^{3} / \mathrm{t} \mathrm{sm}\right]$} & {$\left[\mathrm{m}^{3} / \mathrm{t} \mathrm{smo}\right]$} & \\
\hline Wycierka & $80-90$ & $650-750$ & $52-65$ \\
\hline Sok & $50-56$ & $1500-2000$ & $50-60$ \\
\hline Woda procesowa & $55-65$ & $3000-4500$ & $50-60$ \\
\hline
\end{tabular}

Źródło: Institut für Energetik und Umwelt gGmbH, „Biogaz - produkcja, wykorzystanie“

Kolejnym substratem dla procesów wytwarzania biogazu mogą być „zielone" odpady miejskie. Do odpadów miejskich zalicza się przede wszystkim skoszoną zieleń i trawę powstającą podczas pielęgnacji miejskich parków i pasów zieleni. Podstawową wadą tego podłoża jest jego sezonowa dostępność. W celu zapewnienia całorocznego zapasu tego substratu dla biogazowni, powinien być on odpowiednio zakiszony. Jednak ze względu na dość duże rozrzucenie parków i pasów zieleni w aglomeracji miejskiej, takie działanie nie zawsze jest uzasadnione ekonomicznie i zazwyczaj wiąże się z wysokimi kosztami transportu. Niezależnie od tego zieleń miejska i trawy nadają się także do wykorzystania w biogazowniach jako współsubstrat procesu fermentacji, jak to pokazano w tabeli 3. Ze względu na zbyt dużą zawartość substancji suchej, odpady te nie nadają się do wykorzystania jako pełnowartościowy substrat pojedynczy. 
Możliwości wykorzystania biogazu rolniczego do produkcji paliwa silnikowego

Tabela 3. Uzysk biogazu oraz zawartość metanu w zieleni miejskiej

\begin{tabular}{|c|c|c|c|}
\hline \multirow{2}{*}{ Rodzaj podłoża } & \multicolumn{2}{|c|}{ Uzysk biogazu } & \multirow{2}{*}{$\begin{array}{c}\text { Zawartość metanu } \\
{[\% \text { obj. }]}\end{array}$} \\
\hline & {$\left[\mathrm{m}^{3} / \mathrm{t} \mathrm{sm}\right]$} & {$\left[\mathrm{m}^{3} / \mathrm{t} \mathrm{smo}\right]$} & \\
\hline Skoszona zieleń & $150-200$ & $550-680$ & $55-65$ \\
\hline
\end{tabular}

Źródło: Institut für Energetik und Umwelt gGmbH, „Biogaz - produkcja, wykorzystanie“

\section{Procesy wytwarzania biogazu}

Biogaz powstaje podczas rozkładu materii organicznej w warunkach beztlenowych. Składa się w ok. dwóch trzecich z metanu oraz ok. jednej trzeciej w ditlenku węgla. Poza wspomnianymi gazami w skład biogazu wchodzą również niewielkie ilości wodoru, siarkowodoru, amoniaku oraz innych gazów śladowych. Procentową zawartość składników biogazu przedstawiono w tabeli 4.

Tabela 4. Procentowa zawartość składników biogazu

\begin{tabular}{|l|l|l|}
\hline \multirow{2}{*}{ Skladnik } & Zawartośc & \multicolumn{2}{|l|}{ Srednio (\%) } \\
\cline { 2 - 3 } & Zakres (\%) & 65 \\
\hline Metan (CH4) & $52-85$ & 34,8 \\
\hline Dwutlenek węgla (CO2) & $14-48$ & 0,2 \\
\hline Siarkowodór (H2S) & $0,008-5,5$ & substancja śladowa \\
\hline Wodór (H2) & $0-5$ & substancja śladowa \\
\hline Tlenek węgla (CO) & $0-2,1$ & substancja śladowa \\
\hline Azot (N2) & $0,6-7,5$ & substancja śladowa \\
\hline Tlen (O2) & $0-1$ &
\end{tabular}

Źródło: Oniszk-Popławska A., Owsik M., Wiśniewski G., „Produkcja i wykorzystanie biogazu rolniczego", EC BREC, 2003.

Powstawanie biogazu jest procesem wieloetapowym, którego schemat przedstawiono na rys. 3.

Etap pierwszy to hydroliza, gdzie dochodzi do rozkładu związków takich, jak białka, węglowodory czy tłuszcze, wchodzących w skład materiału wsadowego na proste związki organiczne takie, jak aminokwasy czy kwasy tłuszczowe. Następnie powstałe podczas procesu hydrolizy produkty są dalej rozkładane 
w tzw. fazie kwaśnej na kwasy tłuszczowe oraz ditlenek węgla i wodór. Oprócz tego w fazie tej powstawać mogą niewielkie ilości kwasu 2-hydroksypropanowego (mlekowego) oraz alkoholu etylowego.

Produkty fazy kwaśnej, w trzeciej fazie tzw. octanowej przy udziale odpowiednich szczepów bakterii zamieniają się w kwas etanowy (octowy) oraz wodór i ditlenek węgla. Faza octanowa jest fazą poprzedzającą ostateczne powstanie biogazu.

Ostatnia faza to faza metanogenna, gdzie z produktów fazy octanowej powstaje biogaz.

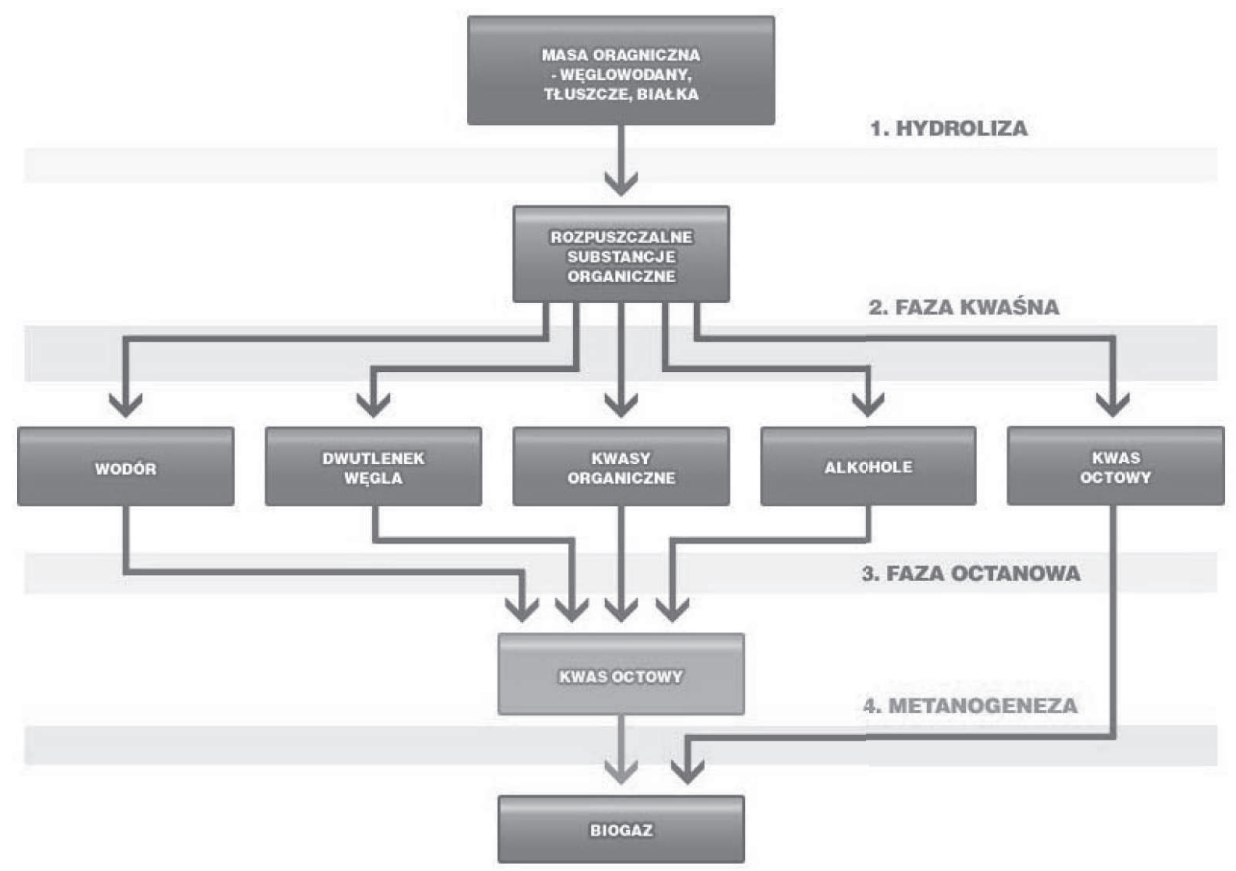

Rys. 3. Etapy powstawania biogazu

Źródło: http://www.e-biopaliwa.pl/bioinformacje/technologie.html

\section{Warunki środowiskowe powstawania biogazu}

Proces powstawania biogazu jest procesem, w którym kluczową rolę odgrywają mikroorganizmy. Podczas poszczególnych etapów produkcji biogazu wykorzystywane są różne rodzaje bakterii posiadających odmienne wymagania odnośnie warunków życia. Stworzenie odpowiednich warunków do życia i namnażania się bakterii jest związane $\mathrm{z}$ tym, czy etapy rozkładu przebiegają $\mathrm{w}$ jednej komorze fermentacyjnej (instalacja jednozakresowa) czy też są rozdzielone na oddzielne komory fermentacyjne (instalacja dwuzakresowa). 
$\mathrm{W}$ przypadku instalacji jednozakresowej warunki panujące $\mathrm{w}$ fermentatorze dobierane są pod kątem bakterii metanowych, które wykazują największą wrażliwość na zmiany w środowisku oraz namnażają się wolno. W instalacjach dwuetapowych następuje rozdzielenie procesu hydrolizy i zakwaszania, co ułatwia stworzenie odpowiednich warunków dla różnych grup mikroorganizmów.

Podstawowymi czynnikami ograniczającymi możliwości wzrostu i rozmnażania się bakterii jest temperatura, zakres $\mathrm{pH}$, odpowiednie składniki pokarmowe oraz zawartość inhibitorów.

Szybkość reakcji chemicznych w zasadzie wzrasta wraz ze wzrostem temperatury. Inaczej jednak wygląda to w przypadku procesów biologicznych. Każdy rodzaj bakterii biorący udział w procesach przemiany materii potrzebuje dla procesów przemiany materii, innych zakresów temperatur. Zbyt niska lub zbyt wysoka temperatura może doprowadzić do zahamowania namnażania się bakterii lub też do nieodwracalnego uszkodzenia ich komórki.

Bakterie biorące udział w procesie rozkładu można, ze względu na wymagania temperaturowe, podzielić na trzy grupy:

- bakterie psychrofilowe; Optymalna temperatura w przypadku bakterii psychrofilowych wynosi ok. $25^{\circ} \mathrm{C}$.

- bakterie mezofilowe; Większość znanych bakterii metanowych posiada optymalną temperaturę wzrostu w mezofilnym zakresie temperatur między 32 a $42^{\circ} \mathrm{C}$.

- Bakterie termofilowe; W przypadku konieczności zabicia bakterii chorobotwórczych lub w przypadku stosowania podłoży o wysokiej temperaturze własnej (np. woda procesowa), zaleca się użycie do fermentacji termofilnych kultur bakterii. Ich optymalna temperatura działania wynosi od 50 do $57^{\circ} \mathrm{C}$. W przypadku optymalnego zakresu $\mathrm{pH}$ obowiązują podobne zależności, jak dla zakresu temperaturowego. Optymalny odczyn $\mathrm{pH}$ bakterii hydrolizujących i kwasotwórczych wynosi od 4,5 do 6,3, niemniej mogą przeżyć również przy nieco wyższym odczynie $\mathrm{pH}$, jednak ich aktywność będzie wówczas znacznie mniejsza. Dla bakterii produkujących kwas etanowy i metan $\mathrm{pH}$ musi zawierać się pomiędzy 6,8 a 7,5.

Do składników pokarmowych zaliczane są pierwiastki śladowe takie jak: Fe, $\mathrm{Ni}$, Co, Se, Mo i W, jako elementy niezbędne do wzrostu i przetrwania bakterii. Ostateczna ilość metanu dająca się uzyskać $\mathrm{z}$ używanych podłoży jest określona poprzez zawartości białek, tłuszczy i węglowodanów. O stabilnym przebiegu procesu decyduje również stosunek $\mathrm{C} / \mathrm{N}$ w używanym podłożu. Do prawidłowego przebiegu procesu stosunek $\mathrm{C} / \mathrm{N}$ musi wynosić w zakresie $10 \ldots 30$. Aby jednak bakterie otrzymywały dostateczną porcję substancji pokarmowych, stosunek C:N:P:S powinien wynosić 600:15:5:1.

Inhibitory to substancje, które już w niewielkich ilościach działają toksycznie na bakterie oraz ograniczają ich działalność hamując w ten sposób proces rozkładu, stąd też powinny być one eliminowane w procesach przygotowania podłoży. Wykaz najczęściej występujących substancji inhibitujących przedstawiono w tabeli 5. 
Izabela Samson-Bręk i Krzysztof Biernat

Tabela 5. Inhibitory procesu wytwarzania biogazu i ich zakresy stężeń

\begin{tabular}{|c|c|}
\hline inhibitor & stężenie \\
\hline sód & między 6 a $30 \mathrm{~g} / \mathrm{l}$ (w przystosowanych kulturach do $60 \mathrm{~g} / \mathrm{l})$ \\
\hline potas & od $3 \mathrm{~g} / \mathrm{l}$ \\
\hline wapń & od $2,8 \mathrm{~g} / \mathrm{l} \mathrm{CaCl}{ }_{2}$ \\
\hline magnez & od $2,4 \mathrm{~g} / \mathrm{l} \mathrm{MgCl}_{2}$ \\
\hline jon amonowy & $2,7-10 \mathrm{~g} / \mathrm{l}$ \\
\hline amoniak & od $0,15 \mathrm{~g} / \mathrm{l}$ \\
\hline \multirow[t]{2}{*}{ siarka } & od $50 \mathrm{mg} / / \mathrm{H}_{2} \mathrm{~S}, 100 \mathrm{mg} / \mathrm{l} \mathrm{S}{ }^{2-}, 160 \mathrm{mg} / \mathrm{l} \mathrm{Na} \mathrm{S}_{2} \mathrm{~S}$ \\
\hline & (w przystosowanych kulturach do 600 mg/l Na $2 \mathrm{~S}$ i 1000 mg/l H ${ }_{2} \mathrm{~S}$ ) \\
\hline \multirow[t]{4}{*}{ metale ciężkie } & jako wolne jony: \\
\hline & $\begin{array}{l}\text { od } 10 \mathrm{mg} / \mathrm{l} \mathrm{Ni} \text {, od } 40 \mathrm{mg} / \mathrm{l} \mathrm{Cu} \text {, od } 130 \mathrm{mg} / \mathrm{l} \mathrm{Cr} \text {, od } 340 \mathrm{mg} / \mathrm{Pb} \text {, od } 400 \mathrm{mg} / \mathrm{l} \mathrm{Zn} \\
\text { w formie weglanowej: }\end{array}$ \\
\hline & $\begin{array}{l}\text { od } 160 \mathrm{mg} / \mathrm{l} \mathrm{Zn} \text {, od } 170 \mathrm{mg} / \mathrm{l} \mathrm{Cu} \text {, od } 180 \mathrm{mg} / \mathrm{l} \mathrm{Cd} \text {, od } 530 \mathrm{mg} / / \mathrm{Cr}^{3+} \text {, od } 1750 \\
\mathrm{mg} / \mathrm{l} \mathrm{Fe}\end{array}$ \\
\hline & metale ciężkie mogą być wyłapywane i neutralizowane przez siarczki \\
\hline $\begin{array}{l}\text { rozgałęzione kwasy } \\
\text { tłuszczowe }\end{array}$ & kwas izomasłowy: działa hamująco już od 50 mg/l \\
\hline
\end{tabular}

\section{Instalacje do wytwarzania biogazu}

Wytwarzanie biogazu na drodze fermentacji beztlenowej odbywać się może $\mathrm{z}$ wykorzystaniem metod według różnych wariantów. W tabeli 6 zestawiono typowe warianty metod produkcji biogazu.

Tabela 6. Metody wytwarzania biogazu w różnych wariantach

\begin{tabular}{|l|l|}
\hline \multicolumn{1}{|c|}{ Kryterium } & \multicolumn{1}{c|}{ Cechy charakterystyczne } \\
\hline $\begin{array}{l}\text { Liczba etapów procesu } \\
\text { technologicznego }\end{array}$ & $\begin{array}{l}\text { Jednoetapowy - brak rozdzielenia równych faz } \\
\text { procesu technologicznego fermentacji,; wszystkie fazy } \\
\text { przeprowadzane są w jednym zbiorniku. } \\
\text { Dwuetapowy - rozdzielność poszczególnych faz procesu na } \\
\text { różne zbiorniki. } \\
\text { Wieloetapowy - rozdzielność poszczególnych faz procesu na } \\
\text { różne zbiorniki. }\end{array}$ \\
\hline $\begin{array}{l}\text { Temperatura procesu } \\
\text { technologicznego }\end{array}$ & $\begin{array}{l}\text { psychrofilowa }-25^{\circ} \mathrm{C} \\
\text { mezofilowa }-32 \ldots 38^{\circ} \mathrm{C} \\
\text { termofilowa }-42 \ldots 55^{\circ} \mathrm{C}\end{array}$ \\
\hline Tryb napełniania materiałem & $\begin{array}{l}\text { Nieciagły } \\
\text { Quasi-ciągły } \\
\text { Ciągły }\end{array}$ \\
\hline $\begin{array}{l}\text { Zawartość substancji suchej } \\
\text { w substratach }\end{array}$ & $\begin{array}{l}\text { Fermentacja mokra } \\
\text { Fermentacja sucha }\end{array}$ \\
\hline
\end{tabular}

Źródło: Institut für Energetik und Umwelt gGmbH, „Biogaz - produkcja, wykorzystanie”. 


\subsection{Proces fermentacji mokrej}

Proces fermentacji mokrej to proces, w którym substrat posiada konsystencję pozwalającą na jego pompowanie (zawartość suchej masy poniżej 15\%). Najbardziej rozpowszechnionym rodzajem fermentacji mokrej jest jednostopniowa fermentacja mezofilowa zawiesiny odpadów o zawartości frakcji stałych od 3 do $8 \%$. Fermentacja prowadzona jest w sposób ciągły w specjalnie przeznaczonych do tego komorach fermentacyjnych. Czas przetrzymywania wsadu w komorze waha się w granicach od 2 do 4 tygodni.

Typowa instalacja do jednostopniowej mezofilowej fermentacji mokrej, przedstawiona na rys. 4 , składa się z pulpera i komory fermentacyjnej. W pulperze odpady przetwarzane są $\mathrm{w}$ taki sposób, aby mogły zostać wpompowane do komory fermentacyjnej. W fermentatorze następuje mieszanie osadów z osadem recyrkulowanym w celu wstępnego ogrzania osadu surowego oraz zaszczepienia go osadem, który znajduje się już w fazie fermentacji metanowej.

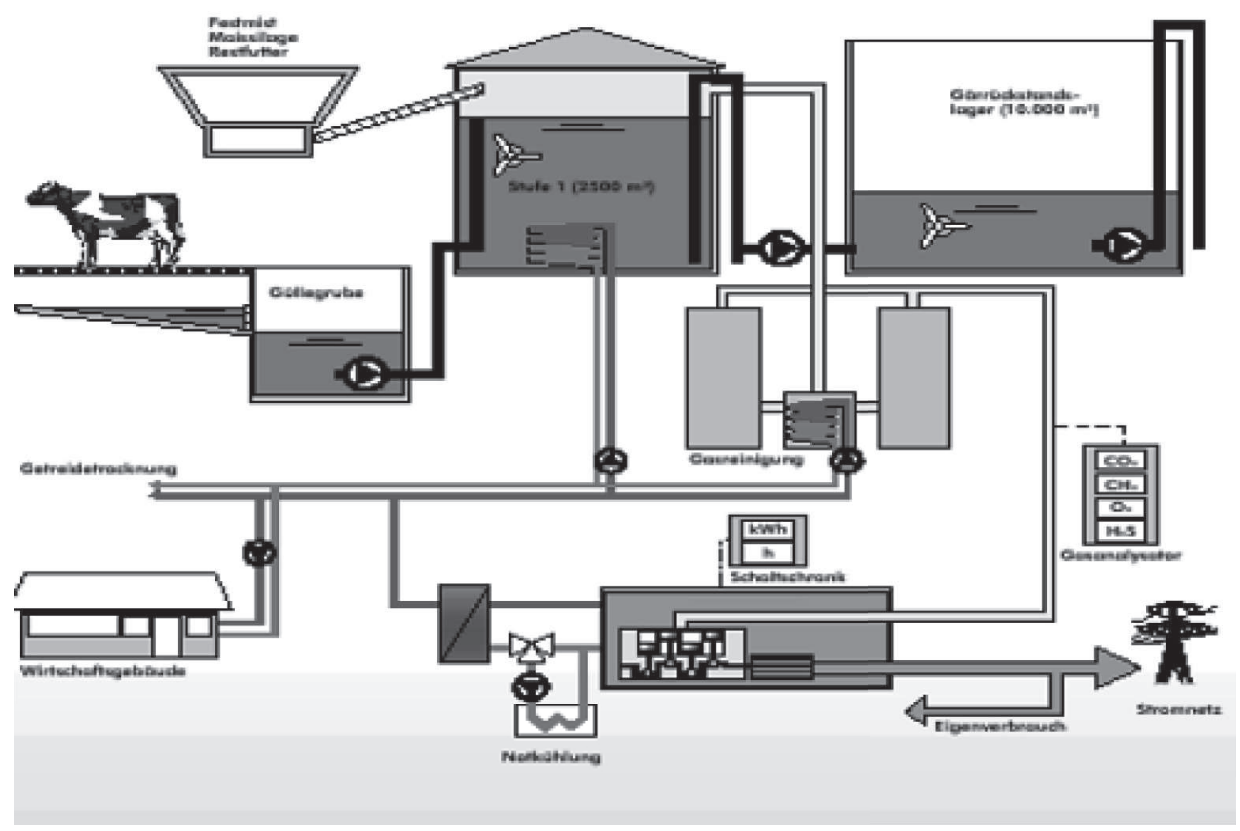

Rys. 4. Schemat procesu jednostopniowej fermentacji mokrej

Źródło: Biernat K., „Bilans energetyczny biogazu w Polsce - metody wykorzystania nagromadzonej w surowcach energii, sporządzanie bilansu energetycznego, planowanie inwestycji pod kątem odbiorców energii, efektywne wykorzystanie zgromadzonego potencjału", materiały konferencyjne. 


\subsection{Proces fermentacji suchej}

Substrat wykorzystywany podczas fermentacji suchej powinien zawierać do $40 \%$ suchej masy. Maksymalne obciążenie reaktora suchą masą organiczną w tym procesie wynosi $10-17 \mathrm{~kg}$ s.m.o. $/\left(\mathrm{m}^{3} \mathrm{x} \mathrm{d}\right)$ przy czasie fermentacji od 15 do 20 dni. Zakłada się, że optymalne obciążenie komory fermentacyjnej oraz maksymalny uzysk biogazu osiąga się przy obciążeniu reaktora wynoszącym $12 \mathrm{~kg}$ s.m.o./( $\left.\mathrm{m}^{3} \mathrm{x} \mathrm{d}\right)$.

\section{Biogaz jako paliwo silnikowe}

Biogaz jako paliwo silnikowe wymaga opracowania odpowiednich metod jego magazynowania, aby maksymalnie zwiększyć zasięg pojazdu wykorzystującego to paliwo. Większe ilości biogazu można zgromadzić w zbiorniku o małej objętości pod odpowiednio wysokim ciśnieniem lub też w postaci ciekłego metanu w zbiorniku kriogenicznym. Takie rozwiązania są jednak mało opłacalne ze względu na wysokie koszty zbiornika.

Objętość gazu, a zarazem pojemność magazynową można zmniejszyć o $25 \ldots 30 \%$ również poprzez „wypłukanie” ditlenku węgla wodą, pod ciśnieniem 15 barów. Jednak mimo to zapotrzebowanie na pojemność magazynową i tak jest znacznie wyższe, niż w przypadku paliw konwencjonalnych. Usuniecie $\mathrm{CO}_{2}$ jest ważne również dlatego, że gaz ten zmniejsza moc użyteczną silnika oraz powoduje zmniejszenie zasięgu pojazdu zasilanego biogazem.

Biogaz z przeznaczeniem do pojazdów powinien zawierać przynajmniej 96\% metanu, stężenie pary wodnej nie powinno być większe niż $15 \mathrm{mg} / \mathrm{m}^{3}{ }_{\mathrm{n}}$, zaś $\mathrm{H}_{2} \mathrm{~S}$ nie powinno przekraczać $100 \mathrm{mg} / \mathrm{m}_{\mathrm{n}}^{3}$. W tabeli 7 przedstawiono szacunkową przydatność biogazu jako paliwa w porównaniu z innymi paliwami.

Tabela 7. Szacunkowa wartość biogazu jako paliwa

\begin{tabular}{|l|c|c|c|}
\hline \multicolumn{1}{|c|}{ Paliwo } & Wartość energetyczna & Samochód Volvo & Wydajność \\
\hline Benzyna & $32,2 \mathrm{MJ} / \mathrm{dm}^{3}$ & V70 biopaliwo & $9,8 \mathrm{~km} / \mathrm{dm}^{3}{ }_{n}=0,30 \mathrm{~km} / \mathrm{MJ}$ \\
\hline Biogaz wzbogacony & $35,9 \mathrm{MJ} / \mathrm{dm}^{3}$ & V70 biopaliwo & $9,6 \mathrm{~km} / \mathrm{m}^{3}{ }_{n}=0,27 \mathrm{~km} / \mathrm{MJ}$ \\
\hline Olej napędowy & $40,7 \mathrm{MJ} / \mathrm{dm}^{3}$ & S60 & $13,2 \mathrm{~km} / \mathrm{dm}^{3}{ }_{n}=0,32 \mathrm{~km} / \mathrm{MJ}$ \\
\hline Biogaz wzbogacony & $35,9 \mathrm{MJ} / \mathrm{dm}^{3}$ & S60 biopaliwo & $10,0 \mathrm{~km} / \mathrm{m}^{3}{ }_{n}=0,29 \mathrm{~km} / \mathrm{MJ}$ \\
\hline
\end{tabular}

Źródło: Institut für Energetik und Umwelt gGmbH, „Biogaz - produkcja, wykorzystanie”.

W zakresie wymagań silnikowych, wymagana jakość biogazu zależeć będzie od zawartości poszczególnych jego składników, czyli stopnia oczyszczania oraz przewidywanych zastosowań jako paliwa. W tabeli 8 przedstawiono wymagania w zakresie zawartości poszczególnych składników biogazu determinujących jego przydatność jako paliwa. 
Możliwości wykorzystania biogazu rolniczego do produkcji paliwa silnikowego

Tabela 8. Dopuszczalne zakresy zawartości składników biogazu do zastosowań energetycznych

\begin{tabular}{|l|c|c|c|}
\hline Składniki biogazu & $\begin{array}{c}\text { Do napędu silników } \\
\text { stacjonarnych }\end{array}$ & $\begin{array}{c}\text { Do zasilania } \\
\text { samochodów }\end{array}$ & Jako składnik gazu ziemnego \\
\hline Ciepło spalania & - & - & $8,4 \ldots 13,1 \mathrm{kWh} / \mathrm{m}^{3}$ \\
\hline $\mathrm{CH}_{4}$ & $\mathrm{~min} .430 \mathrm{mg} / \mathrm{Nm}^{3}$ & $>96 \%$ & nie określa się \\
\hline $\mathrm{H}_{2} \mathrm{~S}$ & $<200 \mathrm{mg} / \mathrm{Nm}^{3}$ & $\leq 5 \mathrm{mg} / \mathrm{Nm}^{3}$ & $<5 \mathrm{mg} / \mathrm{Nm}^{3}$ \\
\hline Merkaptany (tiole) & - & $<15 \mathrm{mg} / \mathrm{Nm}^{3}$ & $\leq 6 \mathrm{mg} / \mathrm{Nm}^{3}$ \\
\hline $\mathrm{CO}_{2}$ & $60 \mathrm{mg} / \mathrm{Nm}^{3}$ & $<3 \%$ & brak górnego limitu \\
\hline $\mathrm{O}_{2}$ & - & $<3 \%$ & $\leq 3 \%($ suchy), $\leq 5 \%$ (wilgotny) \\
\hline Inne węglowodory & - & $<1 \%$ & $<$ punktu rosy \\
\hline Woda & $<80 \%$ & $<0,03 \mathrm{mg} / \mathrm{Nm}^{3}$ & $<$ punktu rosy \\
\hline
\end{tabular}

\section{Wnioski}

Potencjał wytwórczy biogazu w Polsce jest duży i przewyższać może krajowe zużycie gazu ziemnego. Jest to spowodowane głównie tym, że Polska posiada znaczny areał użytków rolnych oraz gruntów odłogowanych i ugorów. Część tych terenów może być wykorzystana do produkcji roślin energetycznych wykorzystywanych jako substrat do produkcji biogazu. Wykorzystanie odchodów zwierzęcych oraz odpadów z przemysłu rolno-spożywczego do produkcji biogazu przyczynia się do zwiększenia bezpieczeństwa energetycznego kraju oraz daje duże możliwości zaspokojenia potrzeb energetycznych.

Stworzenie optymalnych warunków dla rozwoju biogazowni rolniczych, wykorzystujących do produkcji biogazu substraty pochodzenia rolniczego uzasadnia wiele przesłanek. Do najważniejszych z nich należy zaliczyć poprawę bezpieczeństwa energetycznego poprzez oparcie produkcji energii na odnawialnych, krajowych nośnikach energii. Oparcie produkcji energii na lokalnych wytwórniach biogazu pozwala za zapewnienie dostaw biogazu oczyszczonego do jakości gazu ziemnego dla mieszkańców wsi i miasteczek.

\section{Literatura}

1. Biernat K., „Bilans energetyczny biogazu w Polsce - metody wykorzystania nagromadzonej w surowcach energii, sporządzanie bilansu energetycznego, planowanie inwestycji pod kątem odbiorców energii, efektywne wykorzystanie zgromadzonego potencjału", Materiały Konferencyjne. „Projektowanie i finansowanie biogazowni na bazie polskiego rolnictwa i przetwórstwa rolno-spożywczego", Warszawa, 22 czerwca 2009.

2. Biernat K., „Współczesne uwarunkowania i technologie wytwarzania biogazu”, Miesięcznik Naukowo-Techniczny „Chemik, Nauka, Technika, Rynek” nr 7-8, lipiec/sierpień 2008 str. 349355. 
3. Biernat K., „Nowe technologie z wykorzystaniem biomasy do produkcji biogazu”, Konferencja energetyczna, Sejm RP, Warszawa 14.05.2008 r.

4. Biernat K., „Innowacyjne źródła gazu w rolnictwie energetycznym”, Konferencja „Gaz dla Polski”, Warszawa 10 marca 2009.

5. Cebula J., Latocha L., „Biogazownie w gospodarstwach Rolno-Hodowlanych; trendy i kierunki rozwoju”, Instytut Inżynierii Wody i Ścieków Politechniki Śląskiej”.

6. Kozmana M., „Biogaz - polska żyła złota?”, Rzeczpospolita.

7. Lewandowski W., Proekologiczne odnawialne źródła energii”, WNT, Warszawa 2006.

8. Oniszk-Pop£awska A., Owsik M., Wiśniewski G., „Produkcja i wykorzystanie biogazu rolniczego", EC BREC, 2003.

9. SкоRек J., Kalina J., „Gazowe układy kogeneracjne”, WNT, Warszawa 2005.

10. Institut für Energetik und Umwelt gGmbH, „Biogaz - produkcja, wykorzystanie”.

11. Program „Innowacyjna energetyka. Rolnictwo ekologiczne”, Stowarzyszenie Energii Odnawialnej, Polska Izba Biomasy, Polska Izba Gospodarcza Energii Odnawialnej, Stowarzyszenie Niezależnych Wytwórców Energii Skojarzonej.

12. http://www.e-biopaliwa.pl/bioinformacje/technologie.html.

13. http://www.biogaz.com.pl/index.php/home/66-substraty.

\section{Possibilities of using agricultural biogas for the production of engine fuel}

\section{SUMMARY}

Agricultural biogas production and its applications is one of the most favorable methods of receive the energy at present. Thanks to using biogas both to the production of electricity and the warmth and as a engine fuel we can limiting consuming nonrenewable energy sources. Using biogas as a fuel contributing also to reduction of the greenhouse effect mainly thanks to the methane reduction. 